Y. GAO, P. TANG, H. ZHOU, W. ZHANG, H. YANG, N. YAN, G. HU, D. MEI, J. WANG,* D. MA* (PEKING UNIVERSITY, BEIJING, ZHEJIANG UNIVERSITY OF TECHNOLOGY, HANGZHOU, ISRAEL CHEMICALS LTD., SHANGHAI, P. R. OF CHINA; NATIONAL UNIVERSITY OF SINGAPORE, SINGAPORE; AND PACIFIC NORTHWEST NATIONAL LABORATORY, RICHLAND, USA)

Graphene Oxide Catalyzed C-H Bond Activation: The Importance of Oxygen Functional Groups for Biaryl Construction

Angew. Chem. Int. Ed. 2016, 55, 3124-3128.

\title{
Graphene Oxide Promoted C-H Arylation of Benzene with Aryl Halides
}

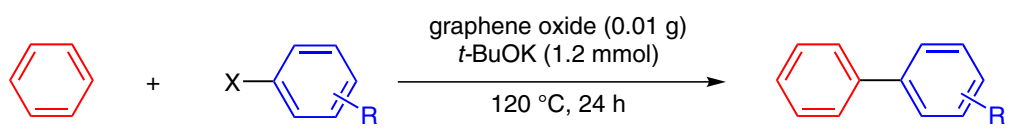

$(4 \mathrm{~mL}) \quad(0.4 \mathrm{mmol}) \quad 15$ examples, up to $92 \%$ GC yield

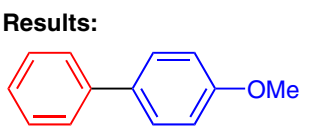

$\mathrm{X}=\mathrm{I}, 88 \%$ GC yield $\mathrm{X}=\mathrm{Br}, 8 \% \mathrm{GC}$ yield

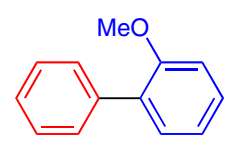

$X=I, 62 \%$ GC yield

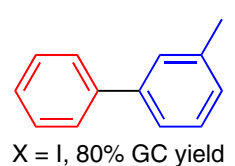

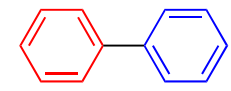

$X=I, 82 \%$ GC yield $\mathrm{X}=\mathrm{Br}, 3 \% \mathrm{GC}$ yield $\mathrm{X}=\mathrm{Cl}, 0 \% \mathrm{GC}$ yield

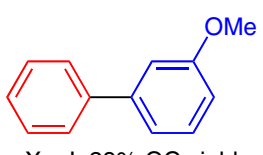

$X=I, 29 \%$ GC yield

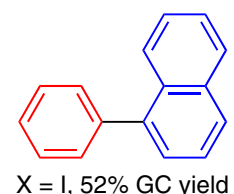

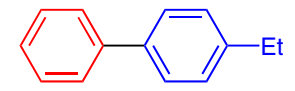

$X=I, 81 \%$ GC yield

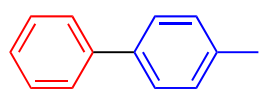

$X=I, 84 \%$ GC yield

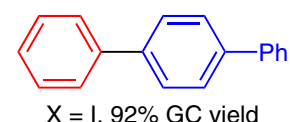

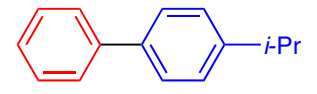

$X=I, 72 \%$ GC yield

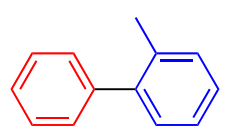

$X=I, 58 \%$ GC yield

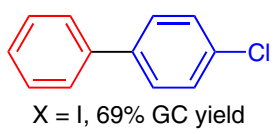

Gategory

Polymer-Supported

Synthesis

Key words

graphene oxide

catalysis

C-H activation

benzene

aryl halides

biaryls

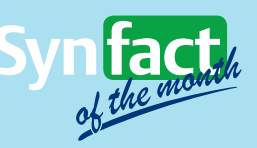

Significance: Graphene oxide promoted the $\mathrm{C}-\mathrm{H}$ arylation of benzene with aryl halides in the presence of $t$-BuOK to give the corresponding biaryls in $\leq 92 \%$ GC yield (15 examples).
Comment: The graphene oxide was characterized by TEM, AFM, Raman spectroscopy, XPS, SEM, and BET analyses. In the reaction of benzene with 4-iodoanisole, the catalytic activity of graphene oxide was superior to that of the other carbon materials (carbon nanotubes: 19\% GC yield, active carbon: $11 \%$, carbon black: 19\%, natural graphite: $8 \%)$. 